\title{
Staphylococcus aureus mitral valve endocarditis due to heel decubitus ulcer
}

\author{
Christina Maria Steger ${ }^{1,2}$ \\ ${ }^{1}$ Department of Pathology, Innsbruck Medical University, Innsbruck, Austria \\ ${ }^{2}$ Department of Pathology, Ludwig-Maximilians-University Munich, Munich, Germany
}

Correspondence to Professor Christina Maria Steger, Christina.Steger@med.uni-muenchen.de

\section{DESCRIPTION}

Bacteraemic infections caused by Staphylococcus aureus have been reported with increasing frequency, and have emerged as the leading cause of infective endocarditis in many regions of the world. ${ }^{1-3}$

Endocarditis is an inflammation of the inner layer of the heart, the endocardium, with involvement of the heart valves (native or prosthetic valves). Other structures that may be involved include the interventricular septum, the chordae tendineae, the mural endocardium or even intracardiac devices. Acute bacterial endocarditis is usually of sudden onset associated with high fever, fast heart rate, fatigue and rapid and extensive heart valve damage.

In August 2011, an 87-year-old non-diabetic woman suffering from a left heel decubitus ulcer, measuring approximately $7 \mathrm{~cm} \times 7 \mathrm{~cm}$, was admitted to hospital to optimise local treatment (figure 1). The patient had been suffering from fever and a burst haemorrhagic bladder on the left heel since a few days. Her medical history included a grade III aortic valve stenosis and a grade II mitral valve stenosis. As a result of a third-degree atrioventricular block she underwent a DDDR pacemaker implantation in 2004.

Physical examination showed a necrotic ulcer on the left heel extending to the muscle and the bone. Laboratory testing revealed a leucocytosis of $23.9 \times 10^{9} / 1$ and an elevated C-reactive protein (CRP) level of $26.34 \mathrm{mg} / \mathrm{dl}$. The patient received $4.0 \mathrm{~g}$ piperacillin and $0.5 \mathrm{~g}$ tazobactam (tazonam; $4.5 \mathrm{~g}$ ) in a $30 \mathrm{~min}$ intravenous

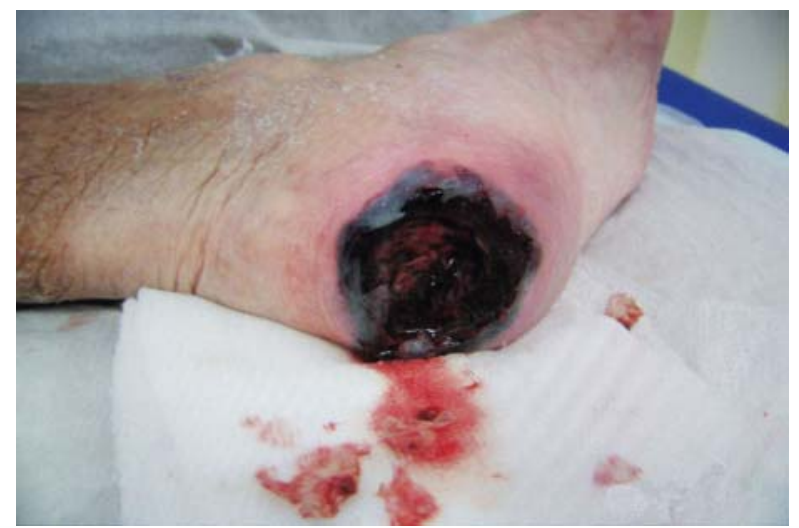

Figure 1 The necrotic heel decubitus ulcer extending to the muscle and the bone. infusion three times per day for 3 days, but on the fourth day after admission to hospital the patient collapsed in the bathroom, suffered sudden cardiac arrest as a result of ventricular tachycardia, and died.

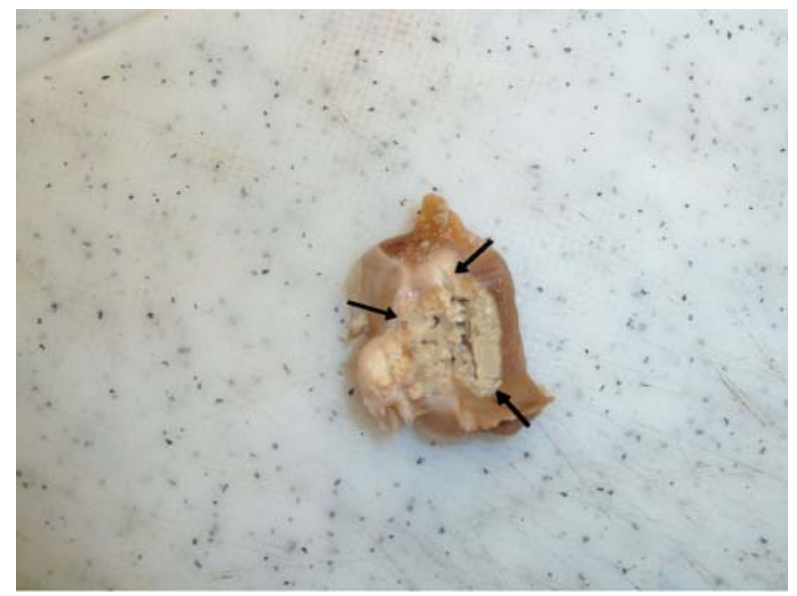

Figure 2 The pus-filled abscess (marked by black arrows) behind the mitral valve with yellowish calcification in the border zone.

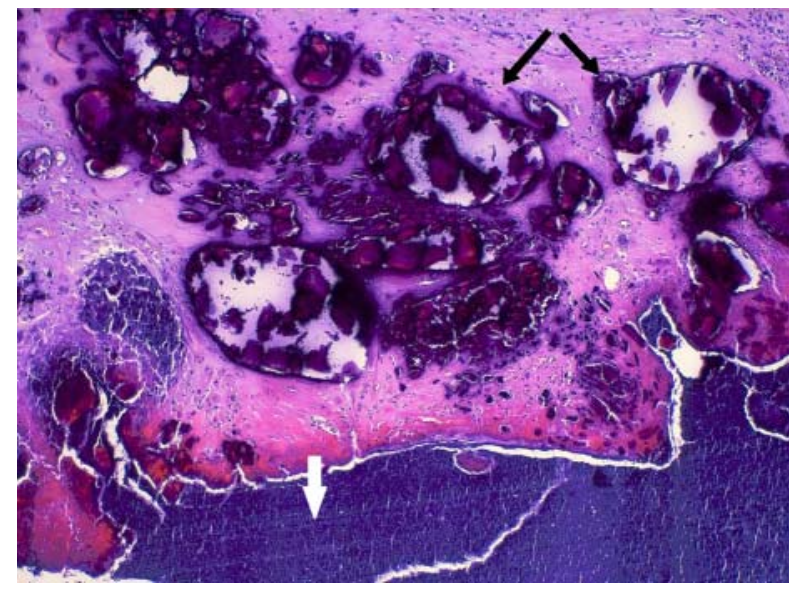

Figure 3 Histological examination of the mitral valve demonstrated severe calcification (coloured violet, black arrows) surrounded by chronic inflammation and bacterial lawn (white arrow, H\&E staining, 200-fold magnification). 


\section{BMJ Case Reports}

Autopsy revealed an extensive septal, left anterior and posterior wall myocardial infarction. In addition, a huge pus-filled abscess more than $2 \mathrm{~cm}$ in size behind the heavily calcified posterior mitral leaflet was found (figure 2). Bacterial examination of the abscess material revealed infective mitral valve endocarditis caused by a methicillin-resistant $S$ aureus being sensitive to only tetracycline, trimethoprim and gentamicin (figure 3).

\section{Learning points}

- Bacterial endocarditis is a life-threatening infectious disease.

- An efficient local treatment strategy for open wounds and the choice of the most appropriate antibiotic treatment are important.
Competing interests None.

Patient consent Obtained.

\section{REFERENCES}

1. Miro JM, Anguera I, Cabell CH, et al. Staphylococcus aureus native valve infective endocarditis: report of 566 episodes from the International Collaboration on Endocarditis Merged Database. Clin Infect Dis 2005;41:507-14.

2. Fowler VGJ, Miro JM, Hoen B, et al. Staphylococcus aureus endocarditis: a consequence of medical progress. JAMA 2005; 293:3012-21.

3. Mylonakis E, Calderwood SB. Infective endocarditis in adults. N Engl J Med 2001;345:1318-30.

This pdf has been created automatically from the final edited text and images.

Copyright 2012 BMJ Publishing Group. All rights reserved. For permission to reuse any of this content visit http://group.bmj.com/group/rights-licensing/permissions.

BMJ Case Report Fellows may re-use this article for personal use and teaching without any further permission.

Please cite this article as follows (you will need to access the article online to obtain the date of publication).

Steger CM. Staphylococcus aureus mitral valve endocarditis due to heel decubitus ulcer. BMJ Case Reports 2012;10.1136/bcr.02.2012.5852, Published XXX

Become a Fellow of BMJ Case Reports today and you can:

- Submit as many cases as you like

- Enjoy fast sympathetic peer review and rapid publication of accepted articles

- Access all the published articles

- Re-use any of the published material for personal use and teaching without further permission

For information on Institutional Fellowships contact consortiasales@bmjgroup.com

Visit casereports.bmj.com for more articles like this and to become a Fellow 